\title{
The Earth is Sick: Environmentalism and the Politics of Age and Gender in Children's Musical Culture
}

\author{
Kai Arne Hansen \\ Inland Norway University of Applied Sciences \\ Kai.hansen@inn.no
}

\begin{abstract}
Anthropogenic climate change is among the most widely debated topics of our time, and recent years have seen the growing impact of children's involvement in environmental issues. While Greta Thunberg and the School Strike for Climate movement are key examples in this regard, there is another tendency deserving of attention that involves the increased prominence of environmentalism in children's music and culture. This article investigates the song and music video Kloden er syk ("The Earth is Sick") by Anna \& Emma, which won the 2019 edition of the Norwegian music competition Melodi Grand Prix Junior. I explore how the audiovisual aesthetics of Kloden er syk encourage solidarity for environmentalist causes, and also discuss disparaging responses to the song and video in order to explicate how age and gender are politicized for the purpose of discrediting young activists and musicians. Ultimately, the article aims to shed light on the distinctly musical (and sociopolitical) ways in which children and young people are implicated in environmental debates.
\end{abstract}

KEYWORDS: Children's popular music, environmentalism, ecomusicology, gender, identity, audiovisual aesthetics

\section{Introduction}

On 23 September 2019, then sixteen-year old environmental activist Greta Thunberg addressed the assembled world leaders at the United Nation Climate Action Summit in New York City. Thunberg's speech - which criticized political inaction by posing the question "how dare you?" - was widely covered by the international media. Photographs of her pained facial expression soon became emblematic of the frustration shared by a generation of climate-conscious children 
and youth faced with mockery from climate contrarians and indecision from politicians (and sometimes also mockery from politicians, as evidenced by US President Donald J. Trump's sarcastic tweet describing Thunberg as a "very happy young girl looking forward to a bright and wonderful future"; see Trump 2019). The young activist, who initiated the now global School Strike for Climate movement, was named Person of the year 2019 by Time Magazine for having inspired millions of people worldwide to declare their support for environmentalist causes.

Anthropogenic climate change and environmental issues are among the most widely debated topics of our time, and children's engagement in these debates have garnered much media attention (see Asmelash 2019; Marris 2019; Turns 2019). While Thunberg and the School Strike for Climate movement represent clear examples of young people's contributions to shaping environmental politics, there is another tendency deserving of attention that involves the increased prominence of environmentalism in children's music and culture (1). Focusing on one aspect of such developments, this article raises the following question: in what ways does pop music made and performed by children contribute to environmental debate? I pursue answers to this question by combining audiovisual analysis and media ethnography with perspectives from ecocritical musicology and gender studies, aiming to exemplify how environmentalist messages in children's music are staged and aestheticized through audiovisual means, and to shed light on the sociopolitical dimensions of the public reception of children's musical environmentalism.

I undertake a reading of Anna \& Emma's Kloden er syk ("The Earth is Sick") (2019) (2), a music video produced for Melodi Grand Prix Junior - a Norwegian music and songwriter's competition for children and adolescents under the age of sixteen. The interpretation of the video provides a point of entry for addressing a range of issues connected to music, aesthetics, and environmental crisis. I also discuss disparaging responses to Kloden er syk, in an effort to explicate how age and gender emerge as factors that are politicized by climate contrarians for the purpose of discrediting young activists.

The article is intended as an initial exploration of the connections between children's musical cultures, environmental concerns, and social politics more broadly, and asserts the significance of children's popular music as a means for expressing ideological views and enabling dialogue on contentious issues. Musical expressions of environmental activism carry the potential to vitalize environmentalist causes for a new generation, and can also function as a mechanism for coming to terms with existential threats. At the same time, children's musical participation in environmental activism exposes them to scrutiny and (potentially) harassment, which problematizes the politics of identity that underpin contemporary environmental debates. By exploring how such tensions play out in the case of Kloden er syk, I direct attention towards the ways in which children's popular song is implicated in global political circumstances, as well as towards the discursive architectures that facilitate both the denigration of children's culture and the minimization of girls' and women's cultural and political influence.

\section{Music and Environmental Crisis}

The interrelation between music and the environment has received increasing attention with the emergence of ecomusicology as a burgeoning (and decidedly broad) field of study. Ecomusicology has been defined by Aaron Allen (2014) as "the study of music, culture, and nature in all the complexities of those terms". A 
principal aspect of such research relates to locating the significance of music for illuminating the relationships between human endeavour, nature, and the environment. According to Allen and Kevin Dawe (2016: 12), ecomusicology "contextualizes and champions the significance of sound and music studies to all life", and seeks to "emphasize people and planet connections and understandings made sonically in a time of crisis". The broad scope of ecomusicological scholarship lays the ground for developing a critical interdisciplinary approach for studying the connections between aesthetics, environmental debates, and the politics of identity.

Underlying scholarly inquiry into music's role in grappling with environmental crisis and its impact on society is the premise that musical expressions have the capacity to influence people on personal, social, and cultural levels. Building on such an assertion, Andrew Mark (2016: 52-53) argues that "the creative arts give language, signification, and ritual to loss, and contribute to the creation of community to recognize and deal with otherwise unspeakable, un-identifiable, unacknowledgeable, and un-grievable loss". Feelings of loss, Mark suggests, are intimately associated with children's experiences of the climate crisis:

As children grow, from what might appear to be a more complete notion of the world, they discover losses of innocence, of nations, of peoples, of places, and they are rarely given the tools, if such exist, to process the histories of incredible violence, loss, and the ongoing present manifestations of colonization and resourcism that they discover. (ibid.: 62)

Given this backdrop, music can emerge as a constructive tool both for voicing environmentalist messages and for processing the anxieties and distress engendered by climate crisis.

Along these lines, music has long been used for the purposes of activism and protest. Music provides "an avenue of cultural contestation or social and political engagement" (Peddie 2006: xvi), which is demonstrated by a long line of popular songs from Woody Guthrie's "This Land Is Your Land" (1945) - the political edge of which was emphasized by the sticker on Guthrie's guitar: "this machine kills fascists" - to Beyoncé's open confrontation of racism in "Formation" (2016). Music's capacity as a vehicle for environmental activism more specifically is well documented in several recent studies (Fuller 2018; Ingram 2010; Lucas 2019). In her research on environmentalism in Icelandic musical culture, Nicola Dibben emphasizes that musical environmentalism is not bound by geographical or national borders but, rather, forms transnational "communities bounded by ideals and actions" (2017: 164). In another investigation of the Icelandic context, Tore Størvold (2019: 411) also advocates the global relevance of musical environmentalist interventions. He argues that a growing awareness of a global ecological crisis now "seeps into artistic sensibilities and practices" (ibid.), and insists that " $(\mathrm{t}) \mathrm{he}$ resulting aesthetics and compositional developments require further exploration by musicologists" (ibid.: 411-412). Allen has similarly called for increased engagement with environmental issues by music scholars:

Environmental crises require all the intellectual, political, scientific, and cultural resources we have to confront them. (...) Given the severity of the environmental crisis and the need to understand and address it in as many ways as possible, it is surprising that sound and music have still not become more common methods to study, organize, educate, and effect change regarding the environment. (2012: 193) 
Such appeals for additional scholarship form part of the impetus for the current study, which aims to make a contribution towards a deeper understanding of the multiple dimensions of aesthetic interventions in environmentalist debates.

My intentional focus on children's musical culture reflects an acknowledgement of the centrality of children in contemporary public discourse concerning environmentalism, as well as an interest in the musical agency of children as both performers and audiences (see Bickford 2012: 418; Hansen 2018: 111ff; Vestad 2019: 206). The former concerns not only the high visibility of young activists in the current media landscape, but also notions of children as the primary victims of anthropogenic climate change (see, for example, Gajanan 2020; Clark et. al 2020). The dual cultural coding of children as influential agents of change and helpless victims results in an ambiguity that shapes the public discourse surrounding children's environmental activism. As exemplified in the case of Kloden er syk, this ambiguity also underpins the reception of children's musical responses to the environmental crisis.

Looking at children's culture more broadly, it is worth noting a long history of incorporating environmentalist themes in cultural texts aimed at children, including books (such as, Dr. Seuss' The Lorax [1971], Jeannie Baker's Where the Forest Meets the Sea [1988]), movies (such as, Bambi [1942], Wall-E [2008]), and TV series (such as, Sesame Street [1969-present], The Animals of Farthing Wood [1993-1995]). It is possible to identify some degree of overlap between the ways in which environmentalism is approached and articulated across these different spheres of children's culture, and I touch on a few of these similarities in the analysis of Kloden er syk. Grappling with the potential of musical and audiovisual aesthetics for inviting contemplation and fuelling debate, I direct attention to Kloden er syk as an example of how children's musical engagement with environmentalism can simultaneously generate a sense of community and stir up broader social conflicts.

\section{The Earth is Sick: Aestheticizing Environmental Activism, Resignification, and Fostering Solidarity}

Melodi Grand Prix Junior (MGPjr), introduced in 2002, is a television music competition for children that is hosted and broadcast by the Norwegian Broadcasting Corporation (NRK). The competition is open to children between the ages of eight and sixteen. Contestants are required to write their own lyrics and melodies, and to sing in a Norwegian or Sámi dialect (NRK Super, n.d.). (The Sámi are an indigenous people inhabiting northern parts of Norway, as well as parts of Sweden, Finland, and Russia.) A small number of contributions are selected for the national finals - ten in 2019 - and these contestants collaborate with professional producers to further develop their songs. Each song is accompanied by a music video, and contestants perform live during the televised national finals where audience votes decide the winner.

There were 1857 songs entered in the competition in 2019. A press release from $N R K$ noted that a high number of songs had addressed environmental concerns, specifically mentioning "plastic and environmentalism" as prevalent lyrical themes (Bergmo 2019). This tendency is exemplified by Kloden er syk, which became the winning contribution of MGPjr in 2019. The song is written by Anna Vestrheim and Emma Helgesen Ylvisåker (hereafter referred to by their stage names, Anna \& Emma), who were both eleven years old at the time of the MGPjr national finals in 
May 2019, and produced by Erlend Elvesveen. Anna \& Emma stated in an interview that they found inspiration for the song in current news, and also highlighted their personal investment in caring for the environment: "we often pick up trash on our way home from school and things like that" (Jenssen 2019). The song's title - The Earth is Sick - aptly sums up its environmentalist message. The lyrics focus on ecological crisis and the exploitation of natural resources, calling attention to their grim consequences: "the sea becomes plastic / the air becomes exhaust / our world needs this to stop now".

The track can generally be described as in the style of an electronic pop power ballad, incorporating elements that are commonly found in the contemporary, EDM-inspired pop mainstream. According to producer Elvesveen, he reharmonized the song and introduced new rhythmic elements and a more expansive instrumentation compared to Anna \& Emma's own recording, which featured only piano and vocals (Olsen 2019). The production is characterized by an array of different synth sounds, digital piano, delay and filter effects, and various programmed percussion and drum patterns. Elvesveen emphasizes the importance of the song's lyrical message, and notes that he sought to add "weight" to the track and increase its dynamics (ibid.). This is manifest in notable contrasts between the verses and choruses.

A single kick drum opens the song with a simple rhythm pattern which recalls a heartbeat, soon followed by layers of pulsating synth sounds that fade in before the first verse begins. The sombre tone of the lyrics - "it gets worse for every passing day" - is underpinned musically by a slow-paced feel and minor tonality. The relatively sparse instrumentation and repetitive accompaniment characterize the first verse, giving prominence to the vocals and lyrical message. The layered, pulsating synth sounds combine with Anna \& Emma's processed vocals - shaped by prominent use of delay and reverb effects - and the confrontational lyrics to establish a gloomy atmosphere, which is imparted partly by the machinic relentlessness of the pulsating synths.

A sense of gloom is further emphasized in the music video, directed by Christoffer Alve. The video opens with images from what appears to be an industrial lot. Emma emerges from a shipping container to sing the opening line of the first verse, with the industrial setting evoking notions of pollution and human intervention in natural environments. The viewing experience is made jarring by abrupt changes in the level of camera zoom, as quick visual edits are synchronized with the kick drum. The result is a somewhat unsettling effect which underpins the severity of the lyrics.

At the start of the pre-chorus (approximately 00:30), Anna \& Emma come across a collection of oil drums (3). Close-up shots of the oil drums reveal rust and chipped paint, emphasizing their function as visual symbols of industrial pollution and the exploitation of natural resources. The musical intensity is heightened significantly at this point by an industrial-sounding percussive hit on the first downbeat of the pre-chorus, its brighter timbre and longer decay contrasting the more subdued kick drum of the first verse. The percussion is placed prominently in the mix and synchronized with images of Anna \& Emma hitting the oil drums with metal rods. These sync points imply that the percussion heard on the track is Anna \& Emma playing on the oil drums. Even though this is clearly not the case, the audiovisual connection is nonetheless significant in informing interpretations of the video and highlighting its environmentalist message.

Anna \& Emma are shown playing along to the percussive hits that drive the prechorus forward. These scenes thus showcase the stylized repurposing of objects that are closely associated with the exploitation of natural resources, for the benefit of 
promoting an environmentalist message. Such an aesthetic strategy resonates with theories of resignification (Butler 2004: 223ff) and reverse discourse (Foucault 1990: 101-102). Butler's (2004: 223) examples of resignification include LGBTQ+ appropriation of the initially derogatory term "queer" and the appropriation of racist language in hip hop and rap, both of which exemplify how resignification can operate as a mechanism for signalling dissent from prevailing cultural paradigms and to empower marginalized groups. Such appropriation does not mean that the resignified terms lose the ability to do harm, however. Sexual and racial slurs, for example, signify very different things depending on who is using them and in what context. Butler (ibid.) emphasizes that resignification can form part of both conservative and radical strategies, and it is not in and of itself an indication of positive social change. Foucault (1990: 101) touched on a similar issue when he argued that there "is not, on the one side, a discourse of power, and opposite it, another discourse that runs counter to it", rather emphasizing the multiple, relational, and unstable effects of discursive strategies. Even if Butler and Foucault are primarily concerned with language, these theoretical perspectives are useful for considering acts of resignification in the musical and aesthetic realms.

Anna \& Emma's use of oil drums for musical purposes in Kloden er syk signals the sociopolitical empowerment of children invested in environmentalist issues. The act of resignification is highlighted by visually striking close-up shots of water splashing from the oil drums in slow motion (approximately 00:31; 01:50; 02:37), which beautifies these objects in a manner that underscores their new function as musical instruments. Granted that oil drums are tools that are both essential for and symbolic of a global petroleum industry whose impact on the environment is considerable (see Heede 2014), Anna \& Emma's reappropriation of them simultaneously calls attention to the pollution of the oil industry and asserts the possibility for alternative uses, as well as for change in both industrial and personal practices. This comes further to the fore in the lyrics during this part of the song, which encourage listeners to "think about which road we should take" because "we can change the world we live in". Even as Anna \& Emma's musical protest does not actually change the primary function of oil drums, then, it offers a way of reimagining reality, exploring new possibilities, and fostering solidarity for environmentalist causes.

The intervention in the symbolic meanings of these industrial artifacts is particularly significant in light of Norway's history as one of the world's largest producers of oil and natural gas, and amidst ongoing debates about impending escalation in offshore drilling. At the onset of the 2020s, Norway is set to drill new oil wells on a larger scale than ever before, which "highlights an awkward contradiction. Norway is both an early-adopter of green technologies (...) and a country whose wealth is built on offshore drilling" (Dunn 2019). This contradiction is implicit in the visuals of Kloden er syk, which present Anna \& Emma in contrasting settings: in an open field and in front of a shipping container, running along the shore of a fjord and beating on oil drums (see Figure 1). The destructive potential of the oil drums (and, by association, the petroleum industry) is accentuated by the contrasting images of natural landscapes. The contrast, in turn, heightens the conspicuousness of Anna \& Emma's repurposing of oil drums to promote an environmentalist message, and calls further attention to the capacity of aesthetic forms for affirming the agency of children vis-à-vis political division and an uncertain future. 


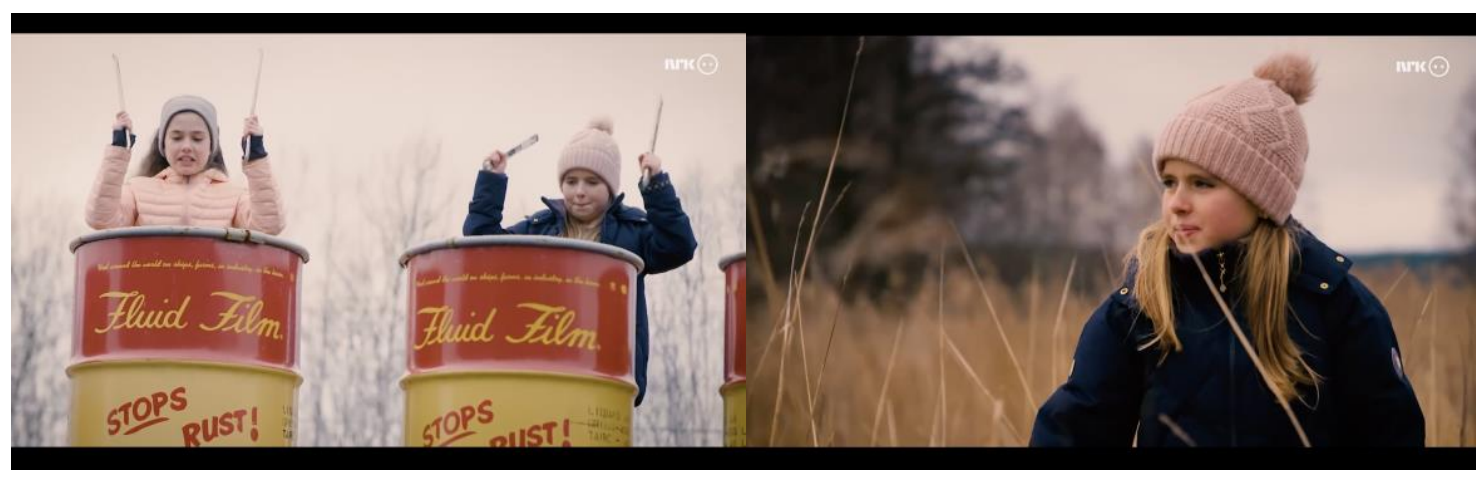

FIGURE 1: Screenshots from Kloden er syk

(dir. Christoffer Alve, 2019). Reproduced with permission from NRK.

The song modulates to E-flat major at the start of the chorus, coinciding with a distinct change in the overall feel as a full beat is introduced. The programmed hihats, characterized by occasional changes in divisions that recall a trap beat, contribute to a distinctly modern sound and add to the increased intensity of the chorus. One of the most striking moments of the video comes in a close-up shot when Anna picks up a handful of sand from a beach and studies it carefully (approximately 00:48), before a contrasting wide-shot pans slowly while Anna \& Emma look out over the fjord. The juxtaposition of these images foregrounds the positioning of the individual within nature, while simultaneously revealing a cultural investment in open landscapes as a symbol for something that is (or should be left) pure and wild. This is in line with a common anti-urban ideal in children's culture, as exemplified by, for example, The Lorax and The Animals of Farthing Wood. In both these examples, humans are presented as exploiting nature, depleting its resources, and destroying animal habitats. Condemnation of such practices underpin Kloden er syk, as in The Lorax and The Animals of Farthing Wood, but the visuals of the video show that more harmonious relations to nature are possible.

Conceptions about the beauty and purity of nature have also been prevalent in the aesthetic practices of popular music, commonly rooted in (national-)romantic discourse and notions of cultural heritage (Dibben 2009; Mitchell 2017; Størvold 2019). As Dibben (2017: 169) notes in relation to popular music's construction of the Icelandic landscape, music is "inspired by and expresses particular views about the natural environment as 'pure wilderness' through its visual, sonic, and linguistic representation". This tendency can be traced in musical protests by Sigur Rós and Björk (ibid.: 169ff; Størvold 2019: 404ff). Dibben (2017: 175) argues that Sigur Rós express (and aid others in experiencing) longing for "a sense of place and emplacement in the face of de-territorialization", while Björk embraces natural phenomena as "the instruments and interfaces for musical creativity" (ibid.: 172173). The scenes on the shore of a Norwegian fjord in Kloden er syk thus add to an existing artistic tradition of imagining closer relationships with nature, and further exemplify how the audiovisual aestheticization of (Nordic) landscapes can serve as a means for protesting the exploitation of natural resources and for envisioning alternative ways of existing in the world.

Kloden er syk advocates social change by addressing the potentially devastating effects of carrying on with human behaviours that risk the welfare of the planet. The description in the second verse of the world "becoming a giant garbage dump" recalls the plot of the animated movie Wall-E, which takes place centuries after 
humans have left an uninhabitable Earth. The movie follows a robot trash compactor assigned with the task of making life on the planet possible again, while humanity is consigned to outer space. The intertextual reference connects Kloden er syk to a cinematic representation of how dire the consequences of continued pollution might be. It is a bleak picture, seemingly painted as a caution for those enamoured of materialistic lifestyles and unwilling to make personal sacrifices for the sake of the environment.

The key message of the song comes towards the end of the chorus with the line "the world needs us to pull ourselves together", the importance of which is emphasized by the prolongation of "together" over two full measures. (That particular word is also placed at the highest point of the vocal melody, on the fifth scale degree of the Eb-major scale, further indicating its significance.) First and foremost, these lyrics seem to straightforwardly encourage transformation: in attitudes towards the environmental crisis and in terms of lifestyle. In context of the video, however, the idea of "pulling ourselves together" also involves "pulling together", joining forces, working towards a common goal. At the exact time that Anna \& Emma sing the word "together" the camera cuts to a close-shot of them joining hands. The importance of working together for the better of the environment is foregrounded in the concluding sentence of the chorus: "the earth is sick, the rest is up to you and me".

Kloden er syk thus presents two distinct but related messages: on the one hand, a call for action, and, on the other, an aspiration for community and solidarity. The former runs as a common thread through the lyrics (for example, "everyone needs to make an effort now"), and is emphasized towards the end of the video. As the final chorus draws to a close, scenes from the beach show Anna \& Emma drawing in the sand. The video cuts to an overhead shot that shows Anna \& Emma run out of the camera's view, to reveal the directive they have written in the sand: "think about it". While this is readily interpreted as intended to prompt environmentalist action, "think about it" can also be read as inviting contemplation, as an encouragement to think differently, consider new possibilities, and envision the future. The latter interpretation is aligned with Dibben's (ibid.: 163) view that "music, as with other cultural practices and products, has a role in environmentalism as a means by which people experience the natural world vicariously, and through which alternative meanings and valuations of nature are asserted". From this perspective, Kloden er syk encourages viewers to think differently about the environment and their relation to it. As Dibben (ibid.: 166) argues, music can "help people to see themselves as part of a global biosphere". She identifies two routes in this regard: "first, the creation of bonds to far distant spaces that have never been experienced first-hand by that individual; and second, by expressing meanings and values that are not about specific places but, rather, about the planet and the 'ecological commons' - those aspects of the natural world that are common to humans" (ibid.). By foregrounding images of Norwegian fjords and landscapes while appealing lyrically to a general environmental conscience, Kloden er syk opens up both of these routes for its viewers, allowing for new cultural and environmental connections.

A contemplative mood is reinforced during the final scene of the video, directly following the reveal of the writing in the sand. The scene depicts Anna in the midst of a field with a thoughtful look on her face as the final notes of the song fade. As with the scenes of Anna \& Emma overlooking the fjord, the aestheticization of Anna's positioning within the landscape encourages (re)consideration of human/nature relationships. The several possible interpretations of the final scene 
of the video reflect the capacity of music (and aesthetics more broadly) for signifying multiple things at once, as well as for serving different purposes. Indeed, if the creative arts serve as channels for voicing one's ideologies, they simultaneously serve as a means for reaching out to other people in the interest of creating dialogue. With regard to the potential of music for bringing people together, Mark suggests that sharing one's concerns and frustrations can contribute to strengthening cultural bonds:

Musicking provides an ethical outlet not merely as emotional ear candy, or only as elegy, but also as a larger systemic process. (...) By directing otherwise harmful emotions (...) towards creative processes like memorialization and melancholic protest, musicking generates community. Musicking to mourn, to alleviate melancholy, and to share loss can be quite efficacious in diffusing tension. (2016: 64)

Mark (ibid.: 65) continues to emphasize that "environmental elegy through song is relevant not merely as a method for calling attention to an issue (...) but as a processual means for collective sublimination, contextualization, healing, and history-keeping in the present". Mark's point about musical environmentalism operating as a form of "history-keeping in the present" raises questions concerning the historical, cultural, and political circumstances in which Kloden er syk participates, which become partly illuminated through an assessment of the media discourse surrounding the video. Investigating the reception of the video vis-à-vis the broader social politics within which young people's climate activism is situated prompts a consideration of how the musical environmentalism of children can spur conflict as much as generate community, and increase rather than diffuse sociocultural tensions.

\section{Reception and the Politics of Age and Gender}

Kloden er syk garnered much attention following the MGPjr national finals, and the event was covered by many Norwegian mainstream media outlets (4). Studying the comments sections of online newspapers and social media reveals much animosity and many disparaging remarks. This is exemplified in responses to the coverage of Verdens Gang ( $V G$ ) and Dagbladet, the two Norwegian newspapers with the highest number of online readers (medienorge, n.d.). $V G$ shared their story about Anna \& Emma's MGPjr victory on their official Facebook page, and the comments posted on the night of the MGPjr finals include: "what climate crisis? It's sick to brainwash kids like this"; "insanity, this climate stuff"; and "the hysteria is on again" (see VG 2019). One of Dagbladet's Facebook posts about the song prompted comments such as "silly girls" and "they should be outside playing instead" (see Dagbladet 2019), further demonstrating the dismissive character of some responses.

The negative comments directed towards Anna \& Emma received national attention later in the year, when $N R K$ published a news story where Emma's mother expressed her concern about how adults belittle and criticize children in the public sphere (Sem et al. 2019). NRK reached out to a number of people who had discredited children's environmental activism online, but only one agreed to be interviewed. Per Gunnar Flåten, who had described Anna \& Emma as "poor brainwashed kids", emphasized that he does not defend online bullying (suggesting that his own comment was in a grey area), but argued that children who write environmentalist songs should have to tolerate criticism and be expected to stand 
for their opinion (ibid.). Such comments resonate with the ambiguous cultural position of pre-adolescent children as simultaneously capable and helpless, and also point to a long history of using personal attacks as a tool for undermining (especially women's) political activism.

To tackle the former first, the close connection in Western culture between childhood and notions of innocence arguably represents one primary influence on the consternation surrounding children's political activism. According to sociologist Doris Bühler-Niederberger (2015), the "notion of innocence refers to children's simplicity, their lack of knowledge, and their purity not yet spoiled by mundane affairs". While "mundane" often describes something dull or uninteresting, its etymological origins can be traced back to the Latin word for "world", and the term is closely associated with the Earth (as opposed to heaven or the spiritual realm). Childhood innocence is thus culturally defined exactly by a lack of understanding of earthly worries, which is exemplified also by Robin Bernstein's (2011: 4) account of an emerging view in the late eighteenth and early nineteenth century of children as "holy angels" who were "oblivious to worldly concerns". Such a cultural insistence on the absence of knowledge in children was solidified by the midnineteenth century, when childhood became "understood not as innocent but as innocence itself: not as a symbol of innocence but as its embodiment" (ibid.) (5).

There is a potential tension in Kloden er syk that emerges from contradicting portrayals of Anna \& Emma as knowing (environmental activism) and innocent (the proper way for children to behave), particularly as a "childish joy" shines through in certain scenes - when they are playing on oil drums, running on the beach - to evoke notions of innocence (and, perhaps, an element of obliviousness with it). The discursive connection between childhood and a lack of knowledge becomes a convenient touchstone for dismissals of Anna \& Emma's environmentalist message, as exemplified by descriptions of them as "poor brainwashed kids" who "should be outside playing instead". At the same time, such responses may be prompted by the incongruity that arises from blurring the boundaries between knowing and innocence, which threatens to destabilize comfortable conceptions of childhood (all the while promoting an environmentalist message that itself is seen as destabilizing by many). Children's ability to surrogate adulthood, as Bernstein (ibid.: 22) argues, is often met with dismay.

Characterizations of Anna \& Emma as "brainwashed kids" and "silly girls" call their (artistic) agency and autonomy into question. This reflects a tendency in Western culture of trivializing the music associated with women and girls (Baker 2001; Coulter 2017), which is rooted in a long history, particularly within the arts, of associating the feminine with a low culture that is seen as "trite, frivolous and inauthentic" (Railton and Watson 2011: 75). Such a discourse places severe constraints on the opportunities (for artistic autonomy, for self-expression, for career development) afforded female musicians in the popular music domain. Furthermore, the attacks on Anna \& Emma's credibility connect to a broader tradition of infantilizing women, which functions as a strategy for minimizing their cultural and political influence.

The disparagements directed towards Anna \& Emma find their equivalents in the more severe debasement of other climate activists, particularly those who are young and/or female. One of the most prominent voices in Norwegian environmental politics, Lan Marie Nguyen Berg of the Norwegian Green Party, has been subjected to severe harassment and threats in addition to widespread ridicule (Giæver and Aronsen 2019). In September 2019, Canada's then Minister of Environment and Climate Change, Catherine McKenna, was assigned additional security following 
sexist online abuse and in-person verbal assaults (BBC 2019). McKenna has also been derisively nicknamed "Climate Barbie" by her critics, including fellow politicians (ibid.). The October 2019 hanging of a Greta Thunberg effigy in Rome demonstrates the intense animosity towards her (Osborne 2019), and critiques of Thunberg frequently take the form of ad hominem arguments that bypass discussion of her political stances by way of personal attacks, as demonstrated by Trump's sarcastic description of her as "a happy young girl". These examples (and many others) reveal the ageist and misogynist underpinnings of ongoing environmental debates (see Nelson and Vertigan 2019).

This issue comes further to the fore in comments about Kloden er syk that rely on words such as "sick", "insanity", and "hysteria" to pathologize Anna \& Emma and undermine their environmentalist message. For centuries, gender scholar and historian Mark Micale (1989: 322) has argued, hysteria in particular "has served as a dramatic medical metaphor for everything that men found mysterious or unmanageable" in women. The pathologization of women's political engagement has historically formed part of widespread silencing strategies in Western societies, as demonstrated by, for example, attempts to delegitimize and stifle the suffragette movement by linking it to deviancy, hysteria, lunacy, and madness (Kay and Mendes 2020). Pathologizing rhetoric thus functions as a mechanism of social control. The aforementioned personal attacks on Thunberg, especially, demonstrate such silencing strategies at work in contemporary environmental debates. The infantilization of Thunberg, media scholar Camilla Nelson suggests, is "invariably accompanied by accusations of emotionality, hysteria, mental disturbance, and an inability to think for oneself - stereotypically feminine labels which are traditionally used to silence women's public speech, and undermine their authority" (Nelson and Vertigan 2019). Notably, the fact that both Thunberg and Anna \& Emma are accused of being brainwashed and labelled hysterical and insane attests to the flexibility with which gendered prejudices cross cultural spheres.

While the negative reception of Kloden er syk takes a milder form than the public denigration of Thunberg (and other activists and politicians), the similarities between the two call attention to the multiple ways in which a gendered rhetoric revolving around "hysteria" and "insanity" contributes to the cultural and political disarmament of women. The dual discrediting of Anna \& Emma's artistry and activism recalls the inequalities that female performers have contended with in the domain of music as much as the proliferation of chauvinism and misogyny in Western culture more generally. At the same time, the reception of Kloden er syk sheds further light on how current environmentalist debates are entwined with sociopolitical discourses with deep historical roots, and highlights the propensity of musical and audiovisual aesthetics for stirring up diverse sets of emotional, ideological, and political responses.

\section{Concluding Thoughts}

If children's music has commonly been dismissed as superficial and unimportant, Kloden er syk aptly demonstrates both the potential of children's popular song for intervening in global political debates and the (often problematic) sociopolitical underpinnings of music performance and reception. The policing of social norms often takes place in cultural spheres that 'go under the radar', in the sense that they are afforded little (if any) credence as sites where narratives about gender, age, and other facets of identity are staged and acted out. Children's music represents one such sphere, where the boundaries of acceptability are continuously under 
negotiation. Acknowledging the sociocultural significance of any musical expression is the first step towards understanding the ways in which children's musical performances can afford new opportunities for grappling with (emotional, ethical, ideological, social) issues related to the environment and anthropogenic climate change.

The environmentalism that underpins Kloden er syk is writ large in the song lyrics, but gains its appeal through aesthetic strategies that activate a range of conceptions about humans, nature, and possible futures. As I hope to have demonstrated, it is through a combination of musical details, production techniques, and visual editing that the environmentalist message of the video appears in full. Musical texts present opportunities for dialogue and ethical confrontation, as Mark (2016: 64) suggests, but also offer audiences much flexibility in their interpretations and responses. Accordingly, Kloden er syk might encourage new ways of thinking about the environment, but can simultaneously contribute to entrenching existing disagreement.

Granted that disparaging comments about Kloden er syk seek to delegitimize its environmentalist message by politicizing age and gender, this further highlights the permeable boundaries between children's musical cultures, popular culture at large, and broader sociocultural and political circumstances. The accusatory and infantilizing language that characterizes the public criticism of both Anna \& Emma and Thunberg reveals the persistence of a troubling tendency to pathologize the political actions of girls and women. By confronting this issue, I aim to prompt further consideration of how the politics of gender and identity play out in children's musical cultures, which is a topic that is rife with opportunities for further research.

In closing, it is worth considering what is overlooked by a study that investigates environmental issues in terms of aesthetics, identity, and meaning. Certainly, focusing on the ways in which music influences debates about climate change risks circumventing, or even obscuring, the negative environmental impact of music production, distribution, and consumption (see Devine 2019). What is the carbon footprint of the MGPjr national finals, hosted in one of the largest music venues in Norway and broadcast to an entire nation? Does prioritizing the aesthetic aspects of musical experience validate a view of music as the most immaterial of the arts, thus diverting attention from its material infrastructures and the environmental costs of music consumption? How do we value the environmentalist contributions of music against more tangible measures to prevent wildfires, reverse rising sea levels, and protect species from going extinct?

These are questions that warrant further contemplation of the myriad ways in which music connects us to and/or separates us from the natural environment. The approach I have chosen in this article is intended to shed light on the distinctly musical and aesthetic ways in which children and young people are implicated in environmental debates, and to demonstrate how such debates are bound up with identity as much as ideology. If I can only hope to have scraped the surface of the topics I have discussed, my ambition is for this article to provide a foundation for future research, as well as to encourage readers to reflect on their own relationships with music, the environment, and the people they share it with.

\section{Endnotes}

(1) This article addresses children's music both as music produced and performed by children and music marketed to children, recognizing that there is often overlap between the two (but certainly not always). It is a central premise of this article that there is also a 
large degree of overlap between children's musical cultures and popular culture more broadly. This is evidenced by the frequent involvement of pop artists in children's movies - recent examples include Beyoncé and The Lion King (2019), Rihanna and Home (2015), and Justin Timberlake and Trolls (2016) - as well as the sometimes immense popularity of adult artists among children, as exemplified by Lil Nas X's performance at a US elementary school in 2019 (see Cantor 2019). Notably, as Tyler Bickford has argued, children's music sounds and looks "increasingly like the mainstream pop aimed at youth and adult audiences. With sophisticated production values, professional songwriting, and talented and stylish performers, the children's music industry has become a powerful force in popular music" (2012: 417; see also Bickford 2020). The permeability of the boundaries between children's music and (popular) music in general also relates to how any musical expression results from and intermingles with a range of cultural, social, and political impulses, which is something that I aim to demonstrate in my discussion of Kloden er syk.

(2) All translations from Norwegian are by the author.

(3) The oil drums are labelled with the brand name Fluid Film, an anti-rust and anticorrosion coating used industrially on cars, ships, planes, and offshore drilling rigs. While Fluid Film is a lanolin-based product, the oil drums are nonetheless symbolic of global industry, pollution, and the exploitation of natural resources.

(4) Emma Helgesen Ylvisåker is the daughter of Vegard Ylvisåker, known from the Ylvis duo who received widespread international attention with the song "The Fox (What Does the Fox Say?)" in 2013. Some of the media coverage of Kloden er syk labored the family connection with headlines such as "celebrity daughter and friend wins MGPjr", which caused some debate concerning press ethics and also spurred criticism against certain newspapers for circumventing the environmentalist message of the song and depriving Anna \& Emma of their artistic agency (see Tetlie 2019). It falls outside the scope of this paper to discuss this issue in any detail, although it is tempting to connect such headlines to the broader discrediting of Anna \& Emma (and other young, female climate activists).

(5) Note that Bernstein (2011: 8) focuses especially on the racial coding of innocence in American culture, arguing that conceptions of childhood innocence as exclusively white "secured the unmarked status of whiteness, and the power derived from that status, in the nineteenth and into the early twentieth centuries". Without going into detail on this topic, I recognize the potential influence of such a discourse in the contemporary Western cultural sphere in which Kloden er syk is situated and participates.

\section{References}

\section{Bibliography}

Allen, A. S. 2014. Ecomusicology. The Grove Dictionary of American Music. New York: Oxford University Press.

Allen, A. S. and Dawe, K. 2016. Ecomusicologies. In A. S. Allen and K. Dawe Eds. Current Directions in Ecomusicology: Music, Nature, Environment. New York: Routledge: 1-15.

Asmelash, L. 2019. Greta Thunberg Isn't Alone. Meet Some Other Young Activists Who Are Leading the Environmental Fight. CNN, 29 September. https://edition.cnn.com/2019/09/28/world/youth-environment-activists-gretathunberg-trnd/index.html Accessed 27 February 2020.

Baker, S. 2001. "Rock On, Baby!": Pre-Teen Girls and Popular Music. Journal of Media and Cultural Studies 15 (3): 359-371. 
BBC. 2019. Catherine McKenna: Canada Environment Minister Given Extra Security. BBC, 8 September. https://www.bbc.com/news/world-us-canada49627153 Accessed 21 September 2020.

Bergmo, T. 2019. Rekordstor påmelding til MGPjr ("Record high participation for MGPjr"). Norwegian Broadcasting Corporation, 23 May. https://www.nrk.no/presse/programomtaler/her-er-finalistene-i-mgpjr-20191.14421750 Accessed 1 March 2020.

Bernstein, R. 2011. Racial Innocence: Performing American Childhood from Slavery to Civil Rights. New York: New York University Press.

Bickford, T. 2012. The New "Tween" Music Industry: The Disney Channel, Kidz Bop and an Emerging Childhood Counterpublic. Popular Music 31 (3): 417436.

Bickford, T. 2020. Tween Pop: Children's Music and Public Culture. Durham: Duke University Press.

Bühler-Niederberger, D. 2015. Innocence and Childhood. Oxford Bibliographies, 28 July. https://www.oxfordbibliographies.com/view/document/obo9780199791231/obo-9780199791231-0161.xml Accessed 7 March 2020.

Butler, J. 2004. Undoing Gender. New York: Routledge.

Cantor, M. 2019. Lil Nas X Gives Surprise Show to a Bunch of Schoolkids... Who Lose Their Lil Minds. The Guardian, 31 May. https://www.theguardian.com/usnews/2019/may/30/lil-nas-x-gives-surprise-show-to-a-bunch-of-schoolkidswho-lose-their-lil-minds Accessed 3 March 2020.

Clark, H. et al. 2020. A Future for the World's Children? A WHO-UNICEF-Lancet Commission. The Lancet Commissions 395 (10224): 605-658.

Coulter, B. 2017. "Singing from the Heart": Notions of Gendered Authenticity in Pop Music. In S. Hawkins Ed. The Routledge Research Companion to Popular Music and Gender. London: Routledge: 267-280.

Dagbladet. 2019. Synger "Kloden er syk», men mange vet nok ikke hvem faren er ("Sings "The Earth is Sick", but Many Won't Know Who Her Father is"), Facebook, 25 May. Available at: https://www.facebook.com/dagbladet/posts/10157353416183118 Accessed 4 September 2020.

Devine, K. 2019. Decomposed: The Political Ecology of Music. Cambridge: MIT Press.

Dibben, N. 2009. Nature and Nation: National Identity and Environmentalism in Icelandic Popular Music Video and Music Documentary. Ethnomusicology Forum 18 (1): 131-151.

Dibben, N. 2017. Music and Environmentalism in Iceland. In F. Holt and A-V. Kärjä Eds. Handbook to Music in the Nordic Countries. Oxford: Oxford University Press: 163-181.

Dunn, K. 2019. Norway Is a Green Leader. It's Also Drilling More Oil Wells Than Ever. Fortune, 18 October. https://fortune.com/2019/10/18/norway-drillingclimate-oil-and-gas/ Accessed 1 March 2020.

Foucault, M. 1990 (1976). The History of Sexuality, Volume 1: An Introduction. Trans. R. Hurley. New York: Vintage Books.

Fuller, K. A. 2018. Voicing Sápmi, Defending Sápmi: Environmental Activism in Sámi Popular Music and Music Videos. Journal of Scandinavian Cinema 8 (2): 103-110. 
Gajanan, M. 2020. Every Child on Earth Faces "Existential Threats" from Climate Change, Report Finds. Time, 19 February. https://time.com/5786395/climatechange-children-threatened/ Accessed 27 February 2020.

Giæver, H. and Aronsen, A. 2019. MDG-Lan utsatt for grov hets i Facebookgruppe ("Norwegian Green Party-Lan Subjected to Severe Harassment in Facebook Group"). Verdens Gang, 11 September.

https://www.vg.no/nyheter/innenriks/i/zGXg61/mdg-lan-utsatt-for-grov-hets-ifacebook-gruppe Accessed 2 March 2020.

Hansen, K. A. 2018. Sangfoni: Magisk realisme, leken læring og identitetsutforsking i barns audiovisuelle musikkultur ("Sangfoni: Magical Realism, Playful Learning, and Exploring Identity in Children's Audiovisual Music Culture"). Studia Musicologica Norvegica: Norwegian Journal of Musicology 44 (1): 102-117.

Heede, R. 2014. Tracing Anthropogenic Carbon Dioxide and Methane Emissions to Fossil Fuel and Cement Producers, 1854-2010. Climatic Change 122: 229_ 241.

Ingram, D. 2010. The Jukebox in the Garden: Ecocriticism and American Popular Music Since 1960. Amsterdam: Rodopi.

Jenssen, M. 2019. Vi har møtt to av finalistene i MGPjr 2019 ("We Have Met Two of the Finalists of MGPjr 2019"). Ris avis. 21 March.

http://www.risavis.net/2019/03/21/vi-har-mott-to-av-finalistene-i-mgpjr-2019/

Accessed 1 March 2020.

Kay, J. B. and Mendes, K. 2020. Gender, Media and Protest: Changing Representations of the Suffragette Emily Wilding Davison in British Newspapers 1913-2013. Media History 26 (2): 137-152.

Lucas, O.R. 2019. "Shrieking Soldiers...Wiping Clean the Earth": Hearing Apocalyptic Environmentalism in the Music of Botanist. Popular Music 38 (3): 481-497.

Mark, A. 2016. Don't Organize, Mourn: Environmental Loss and Musicking. Ethics and the Environment 21 (2): 51-77.

Marris, E. 2019. Why Young Climate Activists Have Captured the World's Attention. Nature 573: 471-472.

medienorge, n.d. Readership of Norwegian Online Newspapers. http://www.medienorge.uib.no/english/?cat=statistikk\&page=avis\&querylD=25 3 Accessed 7 September 2020.

Micale, M. S. 1989. Hysteria and Its Historiography: A Review of Past and Present Writings. History of Science 27 (4): 319-351.

Mitchell, T. 2017. Music and Landscape in Iceland. In F. Holt and A-V. Kärjä Eds. Handbook to Music in the Nordic Countries. Oxford: Oxford University Press: 145-162.

Nelson, C. and Vertigan, M. 2019. Why are Powerful Men So Scared of Greta Thunberg? The Independent, 7 October. https://www.independent.co.uk/news/long reads/women/greta-thunbergclimate-change-crisis-strike-austism-misogyny-protest-speech-a9127971.html Accessed 2 March 2020.

NRK Super. n.d. Regler for MGPjr ("Rules for MGPjr"). Norwegian Broadcasting Corporation. https://nrksuper.no/mgpjr/skriv-en-sang-og-meld-deg-pa-na-10797 Accessed 5 March 2020.

Olsen, E. S. 2019. Han produserte vinnerlåta i årets MGPjr ("He Produced the Winning Contribution of This Year's MGPjr"). Adresseavisen. 
https://www.adressa.no/pluss/kultur/2019/05/27/Han-produserte-vinnerlåta-iårets-MGPjr-19125569.ece Accessed 7 September 2020.

Osborne, S. 2019. Greta Thunberg: Hanging Effigy of Teenage Climate Activist Strung Up in Rome. The Independent, 8 October. https://www.independent.co.uk/news/world/europe/greta-thunberg-hangingeffigy-rome-italy-climate-change-protest-a9147021.html Accessed 2 March 2020.

Peddie, I. 2006. Introduction. In I. Peddie Ed. The Resisting Muse: Popular Music and Social Protest. Aldershot: Ashgate: xvi-xxiv.

Railton, D. and Watson, P. 2011. Music Video and the Politics of Representation. Edinburgh: Edinburgh University Press.

Sem, V. et al. 2019. Mor til MGPjr-vinner opprørt over kommentarfeltet: - Vær så snill, ikke snakk nedsettende til barn ("Mother of MGPjr-Winner Worried About Comment Sections: Please, Don't Talk Down to Children"). Norwegian Broadcasting Corporation, 10 November. https://www.nrk.no/norge/mor-tilmgpjr-vinner-opprort-over-kommentarfeltet - -vaer-sa-snill -ikke-snakknedsettende-om-barn-1.14774740 Accessed 2 March 2020.

Størvold, T. 2019. Music and the Kárahnjúkar Hydropower Plant: Style, Aesthetics, and Environmental Politics in Iceland. Popular Music and Society 42 (4): 395-418.

Tetlie, K. 2019. MGPjr-vinnere ble til "Ylvis-datter og venninne" i media ("MGPjr Winners became "Ylvis-daughter and friend" in the Media"). Dagbladet, 28 May. https://www.dagbladet.no/kultur/mgpjr-vinnere-ble-til-ylvis-datter-ogvenninne-i-media/71120509 Accessed 2 March 2020.

Trump, D. J. 2019. She seems like a very happy young girl looking forward to a bright and wonderful future. So nice to see!, Twitter, 24 September. Available from: https://twitter.com/realDonaldTrump/status/1176339522113679360 Accessed 3 March 2020.

Turns, A. 2019. Meet Generation Greta: Young Climate Activists Around the World. The Guardian, 28 June.

https://www.theguardian.com/environment/2019/jun/28/generation-gretayoung-climate-activists-around-world Accessed 27 February 2020.

Vestad, I. L. 2019. Re-thinking Systems of Meaning-Making: A Possible Theoretical Framework for Exploring Children's Engagement in Music and the Subject Positions of "Rock-Boys" and "Pop-Girls". In S. Young and B. Ilari Eds. Music in Early Childhood: Multi-disciplinary Perspectives and Inter-disciplinary Exchanges. Cham: Springer: 203-221.

VG. 2019. Anna og Emma vant med låten «Kloden er syk», en låt om klimakrisen ("Anna and Emma Won With the Song "The Earth is Sick», a Song About the Climate Crisis"), Facebook, 25 May. Available from: https://www.facebook.com/vgnett/posts/10157499510821995 Accessed 2 March 2020.

\section{Discography}

Anna \& Emma. 2019. "Kloden er syk", MGPjr 2019, Aiko Music, 12 April. Beyoncé. 2016. "Formation", Lemonade, Parkwood Entertainment, 23 April. Woody Guthrie. 1945. "This Land is Your Land", Ten of Woody Guthrie's Songs (Pamphlet). 
Ylvis. 2013. "The Fox (What Does the Fox Say?)", The Fox, Parlophone / Warner Music, 1 January.

\section{Videography}

Bambi. 1942. Dir. David Hand et al., Walt Disney Productions.

Home. 2015. Dir. Tim Johnson, DreamWorks Animation / 20th Century Fox.

Kloden er syk. 2019. Dir. Christoffer Alve, Aiko Music / Norwegian Broadcasting Corporation.

The Lion King. 2019. Dir. John Favreau, Walt Disney Pictures.

Trolls. 2016. Dir. Mike Mitchell and Walt Dohrn, DreamWorks Animation / $20^{\text {th }}$ Century Fox.

Wall-E. 2008. Dir. Andrew Stanton, Walt Disney Pictures / Pixar Animation Company. 